DOI 10.18551/rjoas.2019-12.06

\title{
ANALYSIS OF STAKEHOLDERS' ROLE IN DEVELOPMENT OF BANDUNGAN CHRYSANTHEMUM AGROTOURISM AT SEMARANG DISTRICT, INDONESIA
}

\author{
Mardiana Ike ${ }^{\star}$, Mukson \\ Faculty of Animal and Agricultural Sciences, University of Diponegoro, Semarang, Indonesia \\ Susilowati Indah \\ Faculty of Economics and Business, University of Diponegoro, Semarang, Indonesia \\ *E-mail: ikemardiana580@gmail.com
}

\begin{abstract}
Sustainable tourism development program requires the cooperation of various tourism actors. The active role of stakeholders, including government, private sector, community and academics is needed to optimize the success of tourism development. Semarang Regency, with an area of $950.21 \mathrm{~km}^{2}$, with 19 sub-districts and 696,556 productive age of a total population of 1,014,198 (BPS 2017 Semarang Regency) has a large potential of resources and tourism growth. This is seen from the tourist visits that always increase. From the data of the Statistics Agency for tourism visits to Semarang Regency, there was an increase of 19$24 \%$ from 2015 - 2017. Sustainable agro-tourism management cannot only offer tourism potential and attractiveness, but there must be cooperation from various parties involved and each stakeholder has role for the successful development of sustainable Bandungan chrysanthemum agro-tourism. The research method uses stakeholder analysis with data on the influence and interests of each stakeholder. This research was conducted by identifying all stakeholders involved in the management of Setya Aji Flower Farm, grouping of stakeholders based on interests and influences so as to obtain key stakeholders who have the greatest influence and interest in developing Setya Aji Flower Farm. Based on the research identified 11 stakeholders who played a role in the management and development of Setiya Aji Flower Farm consisting of government, community, academics and the private sector. From the results of the analysis the key stakeholders are the Setya Aji Flower Farm Management Group, farmers and local community. The three stakeholders can improve communication and can synchronize work activities and programs and be able to collaborate with other stakeholders in developing chrysanthemum agrotourism so that the objectives of tourism development, agricultural and economic product development can be achieved.
\end{abstract}

\section{KEY WORDS}

Agro-tourism, stakeholders, governance, public service.

Tourism is one of the potential sectors in contributing Gross Domestic Product, foreign exchange and employment in Indonesia contributing 5\% of national GDP in 2017 and the Government is targeting $8 \%$ for 2019. The number of foreign tourists visiting Indonesia from 2011 to 2018 experienced an increase and the highest was $21.88 \%$ in 2017.

Semarang Regency has a large potential for resources and tourism growth. This is seen from the tourist visits that always increase. From the data of the Statistics Agency for tourist visits to Semarang Regency, there was an increase of 19-24\% from $2015-2017$ with a total of tourists visiting 2,502,333. (Source: BPS 2017 Semarang Regency). Bandungan District, a part of Semarang Regency, has volcanic soil and cool mountain temperatures to support the development of flower and vegetable plantations. Based on Central Java BPS data in 2016, Semarang Regency is the largest chrysanthemum production center in Central Java with 136,149,950 production from a total of 137,970,928 stems and spread in 3 districts namely Bandungan (87.5\%), Sumowono (12.2\%) and Ambarawa (0.3\%). The combination of agricultural potential, natural scenery and community life that supports the above makes Bandungan District a chance to become a prospective agrotourism. This research will focus 
on Setya Aji Flower Farm, Jetis Village, Bandungan District which is a chrysanthemum flower agrotourism managed by local community. The concept of agro-tourism is also simple, that is utilizing chrysanthemum flowers before harvesting for tourism or taking photos to enjoy its beauty.

Setya Aji Flower Farm was opened to the public in 2016 and was able to attract many tourists with an average number of visitors 8,997 tourists per month. The peak of tourist visits occurred in July 2017 with 13,423 visitors. But starting in February 2018 the number of visitors will decrease due to the opening of new tourism objects with the concept of a flower garden around Bandungan, which attracts many tourists to visit there. Sustainable management of agro-tourism can not only offer the potential and attraction of tourism, but there must be cooperation between the various parties involved and each stakeholder, namely the Government, the private sector, the community and academics, who have a role for the successful development of sustainable Bandungan chrysanthemum agro-tourism.

The purpose of this study is to identify stakeholders who manage chrysanthemum agro tourism; analyze the role of stakeholders in the development; formulating governance models of chrysanthemum agrotourism in Bandungan District.

\section{METHODS OF RESEARCH}

The research location is Setiya Aji Flower Farm Bandungan, Jetis Village, Bandungan District, Semarang Regency, considering that it is a chrysanthemum flower agrotourism managed by local community groups. The method used is Stakeholder analysis to determine the priorities of competent stakeholders involved in terms of identifying factors that influence the development of chrysanthemum agrotourism in Bandungan District.

The definition of stakeholders according to Hetifah (2003) is interpreted as individuals, groups or organizations that have interests, are involved, or are influenced by development activities or programs. Whereas stakeholder analysis is an approach by identifying key actors and assessing their respective interests in the system (Suporahardjo 2005). According to Reed et al. (2009) stages in stakeholder analysis namely identifying stakeholders, classifying stakeholders and investigating stakeholder relationships. According to Eden and Ackkermann (1998) referred to in Reed et al (2009) the analytical method used uses a matrix of influence and interests by classifying stakeholders into key players, context setters, subjects and crowds.

Field surveys and observations are conducted to collect data by distributing structured questionnaires and interviews. Respondents were chosen deliberately (Purposive sampling) based on the needs of research data ie those who have special expertise (experts), respondents who are key figures who are considered to have the ability and understand the problems with the development of Setiya Aji Flower Farm include representatives from government elements (Department of tourism, agriculture, sub-district and village offices, private sector (travel agent), academics and community (Setiya Aji management group, trader, local community, farmers and traveler). Data analysis is carried out as follows: Identification of all stakeholders and related information such as roles, departments, interests, knowledge, and level of influence, as well as potential support for each stakeholder that can be developed and classified for strategy development.

\section{RESULTS AND DISCUSSION}

The results of the study identified 11 stakeholders involved in the development of Setiya Aji Flower Farm governance as many as 11 stakeholders which were divided into Government Groups, Private Groups, Community Groups \& Academic Groups. The stakeholders of the Government group are tasked with facilitating \& providing support to improve the human resources of tourism actors \& farmers to improve the economy. Private groups are business people, Travel agent. The aim is to support the development of Setiya Aji Flower Farm by promoting tourism and providing tourist support infrastructure. Academic groups or universities, namely Diponegoro University, are institutions that are actively 
involved in several activities such as research \& field practice to Setiya Aji Flower Farm. The community groups are represented by the Setiya Aji Management Group, the Setiya Aji Traders Group, farmers, local communities and traveler with their respective roles.

Table 1 - Setiya Aji Flower Farm Stakeholders

\begin{tabular}{lll}
\hline \hline No & Classification & Agency \\
\hline 1 & Government & Tourism Department \\
& & Agriculture Department \\
& Sub-District \\
& Village \\
2 & Private sector & Travel Agent \\
3 & Community & Farmer \\
& & Management of Setiya Aji Flower Farm \\
& & Trader \\
& & Local community \\
& & Traveler \\
4 & Academics & University of Diponegoro \\
\hline
\end{tabular}

The management of Setiya Aji Flower Farm involves several stakeholders. The role of each stakeholder will determine the future agro-tourism development strategy. For this reason it needs to be analyzed using the stakeholder analysis method by knowing who the stakeholders are and grouping them based on depth interview. The following results are the results of the influence and interests of each stakeholder.

Table 2 - Results of stakeholder interests and influence

\begin{tabular}{|c|c|c|c|c|c|c|c|c|c|c|c|c|c|}
\hline \multirow[t]{2}{*}{ No } & \multirow{2}{*}{ Stakeholders } & \multicolumn{5}{|c|}{ Influence } & \multirow{2}{*}{$\begin{array}{c}\text { Total } \\
(\mathrm{X})\end{array}$} & \multicolumn{5}{|c|}{ Interest } & Total \\
\hline & & P1 & P2 & P3 & $\mathrm{P} 4$ & P5 & & $\mathrm{K} 1$ & $\mathrm{~K} 2$ & K3 & $\mathrm{K} 4$ & K5 & $(\mathrm{Y})$ \\
\hline 1 & Tourism Dept & 3 & 3 & 2 & 2 & 2 & 12 & 2 & 2 & 2 & 2 & 1 & 9 \\
\hline 2 & Agriculture Dept & 1 & 1 & 1 & 2 & 1 & 6 & 2 & 1 & 1 & 1 & 1 & 6 \\
\hline 3 & Sub District & 2 & 2 & 2 & 1 & 1 & 8 & 2 & 2 & 2 & 1 & 1 & 8 \\
\hline 4 & Village & 4 & 3 & 3 & 3 & 3 & 16 & 2 & 2 & 2 & 1 & 2 & 9 \\
\hline 5 & Farmer & 4 & 3 & 2 & 4 & 4 & 17 & 4 & $\overline{4}$ & 3 & 3 & 3 & 17 \\
\hline 6 & Local community & 3 & 2 & 2 & 3 & 2 & 12 & 3 & 3 & 3 & 2 & 3 & 14 \\
\hline 7 & Management of Setiya Aji & 3 & 3 & 3 & 3 & 4 & 16 & 4 & 4 & 3 & 4 & 4 & 19 \\
\hline 8 & Trader & 2 & 2 & 2 & 2 & 2 & 10 & 2 & 3 & 2 & 3 & 3 & 13 \\
\hline 9 & Travel Agent & 2 & 2 & 1 & 2 & 2 & 9 & 1 & 2 & 1 & 1 & 2 & 7 \\
\hline 10 & Traveler & 1 & 2 & 1 & 1 & 1 & 6 & 1 & 1 & 1 & 1 & 1 & 5 \\
\hline 11 & Academics & 2 & 2 & 1 & 1 & 2 & 8 & 1 & 1 & 1 & 1 & 1 & 5 \\
\hline
\end{tabular}

Influence:

4: Very high; 3: height; 2: high enough; 1: less high; 0: low;

P1: Stakeholders' ability to fight for their aspirations in the development of agrotourism;

P2: Stakeholder ability in implementing Setiya Aji Flower Farm tourism development;

P3: Stakeholder human resource capacity that is active in the development of agrotourism;

P4: Contribution of stakeholder facilities or infrastructure provided in the development agrotourism;

P5: Stakeholder allocation of resources in the development of agrotourism.

Importance:

K1: Stakeholder involvement in the development of agrotourism;

K2: Agro-tourism development is a stakeholder priority;

K3: Stakeholder authority in the development of agrotourism;

K4: Benefits of the development of agrotourism for stakeholders;

K5: Stakeholder links to agro-tourism development.

From the results of the total value of the importance and influence of each stakeholder is poured in a stakeholder matrix which is divided into 4 quadrants as in Figure 1.

Stakeholders included in quadrant I (subject) are parties with high interests but have low influence. Stakeholders included in the subject category consist of groups of tourist traders. This stakeholder has an important role in the development of Setiya Aji Flower Farm. According to Yoeti (1997: 2) the requirements of a tourist attraction are something to see, something to do and something to buy. The presence of traders in Setiya Aji agro-tourism is 
one of the important points to attract tourists to visit. Traders provide distinctive souvenirs such as chrysanthemums and other ornamental plants, food and drinks needed by tourists.
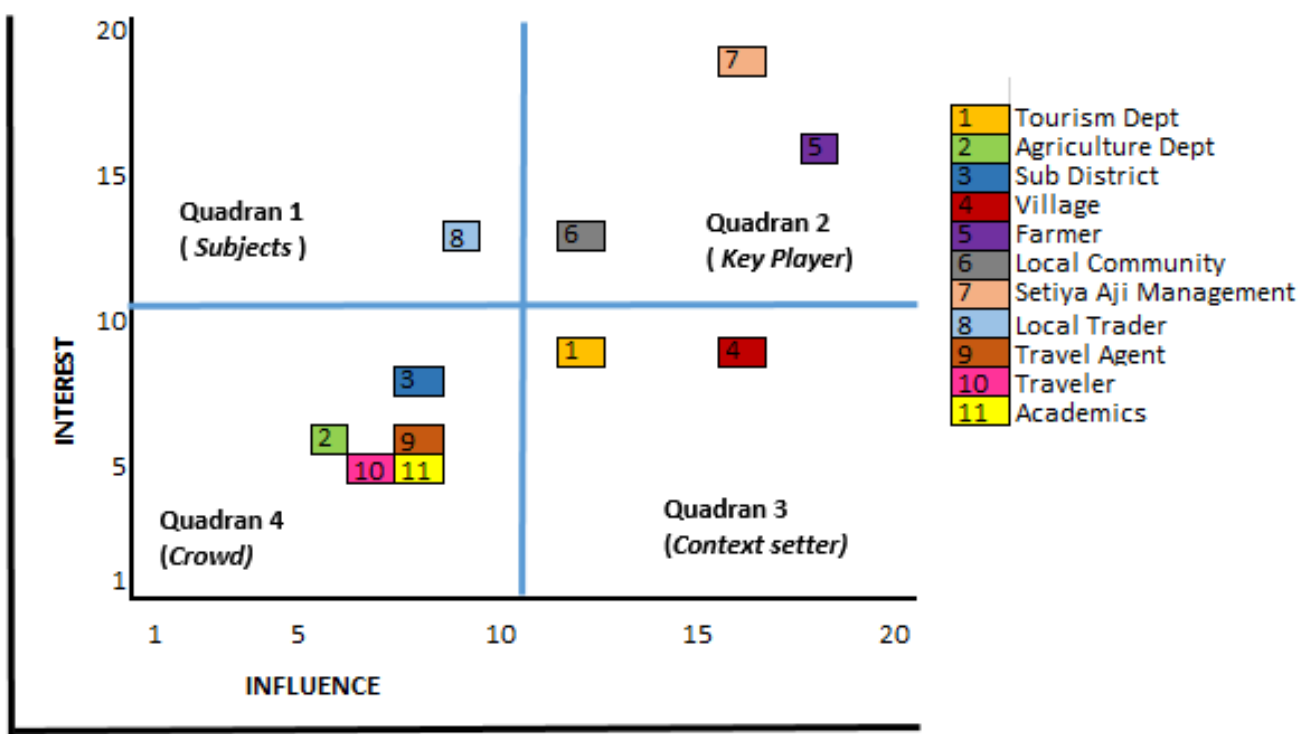

Figure 1 - Matrix of stakeholder interests and influences in the management of Setiya Aji Flower Farm agro-tourism

Quadrant II (Keyplayer), namely stakeholders who have high influence and importance. The stakeholders included in this quadrant are the Farmers, Setya Aji Management Group and the community. These three stakeholders have the highest role in developing Setya Aji agro-tourism. Farmers are the biggest influential actors because they provide chrysanthemums as their main tourism objects. While the importance is also high, because before it was known as agro-tourism, the source of farmers' income was only from the sale of chrysanthemum flowers. After Setiya Aji Flower Farm develops, the farmer earns $40 \%$ of the revenue sharing for the garden visited by tourists before the harvest, while farmers can also sell chrysanthemums directly to visitors at a higher price of Rp. 5,000 per stalk, whereas if farmers sell to traders between Rp. 1,500 up to Rp. 2,500 per stalk. Research (Lestariningsih: 2018) there was an increase in chrysanthemum farmers' income in Bandungan District after the existence of agro-tourism. The average income of farmers after the existence of agrotourism is Rp 31,713,636 / year higher than the income of farmers before the existence of agro-tourism is Rp 30,395,843 / year. The Setiya Aji Management Group has a high influence because it is responsible for managing and developing agrotourism. Managers seek facilities in agro-tourism locations, for example by providing photo spots, gazebos for visitors to rest, while also managing entrance tickets and parking. The interests of the Setiya Aji Management Group are high because they get a share of $30 \%$. While the community also has an important role by providing land for parking and providing comfort with hospitality to tourists. This becomes a symbiosis of mutualism where the community also requires the presence of visitors to improve the level of their economy with a variety of things, such as becoming a guide, or can also be a forum for the surrounding community to promote other local superior products, for example the Vienna Avocado seeds.

Stakeholders included in quadrant III (Context setter) have a high influence but low importance. Villages and tourism offices have a high influence that can influence the development of Setiya Aji Flower Farm. The village has great authority to utilize resources for the benefit of the region. Chrysanthemum agrotourism stands on village-owned land managed by farmers with a production sharing system. The village also has the authority to distribute Village funds to the village's mainstay programs. Setiya Aji Flower Farm also received financial assistance to concretize roads in the chrysanthemum garden area. This greatly supports the development of agro-tourism, because the path to the chrysanthemum 
flower gardens that have not been concrete is not comfortable to pass, especially if it rains, it will become muddy and slippery. With the help of a concrete footpath will facilitate road access for tourists. The village has a low interest in Setiya Aji Flower Farm at this time, because there are no funds coming in as local revenue. The Tourism Department has a great influence on the development of Setiya Aji Flower Farm. The Tourism Department can be function as a mediator as well as a media for gathering and providing information on tourism. The Department of Tourism provides training of tour guides, meeting partners and provides facilities for comparative studies to other tourist objects that have been developed for tourism managers.

Crowd is a stakeholder with low interests and influence. The Department of Agriculture, Subdistricts, Travel Agent, Traveler and Academics are stakeholders who contribute but are not directly involved in the development of Setiya Aji Flower Farm. The Department of Agriculture provides support to farmers in the form of counseling and also the provision of agricultural equipment such as tractors and farming tools. Indirectly play a role in the development of agrotourism, because with the support of the Department of Agriculture, farmers can produce a good chrysanthemum and will be a visitor attraction for the beauty of the chrysanthemum flowers produced. The sub-district functions as a socio-cultural control of agro-tourism management in accordance with applicable rules and social order. The travel agent has a role in promoting Setiya Aji Flower Farm to tourists in the form of tour packages. Currently there is not much that can be done and utilized by the group of tourist bureaus to Setiya Aji Flower Farm because currently there are no tour packages provided by the Setiya Aji. If the tour packages are available and seriously worked on it could be that the role of the tourism bureau will shift to other quadrants that have a greater role in the development of agro-tourism. Traveler do not play a direct role in Setiya Aji's agro-tourism, but with the rise of social media trends in almost all circles, social media users are eager to upload something interesting. By taking pictures in the chrysanthemum agro-tourism area and uploading it to social media like Facebook, Instagram, WhatsApp will make people interested to visit too. This can be an effective and inexpensive promotional media. Academics play an indirect role through education and research, for example about assessing tourist satisfaction levels and agro-tourism development strategies. From this research, things that can be used for the development of agro-tourism can be applied.

The management of Setiya Aji Flower Farm agrotourism is determined by several objectives related to all stakeholders. The objectives of the management are: (1) The management of Krisan agrotourism Setiya Aji determined several goals related to all stakeholders. The objectives of the management are: (1) Increasing tourism potential, (2) Increasing the economy, (3) Increasing agricultural output. The position of the stakeholders' competitiveness assessment scale towards the goals of agro-tourism management shows that all stakeholders support these goals as in Figure 2 histogram of the stakeholder's implications for the purpose of agro-tourism management with data that is processed using Mactor software.

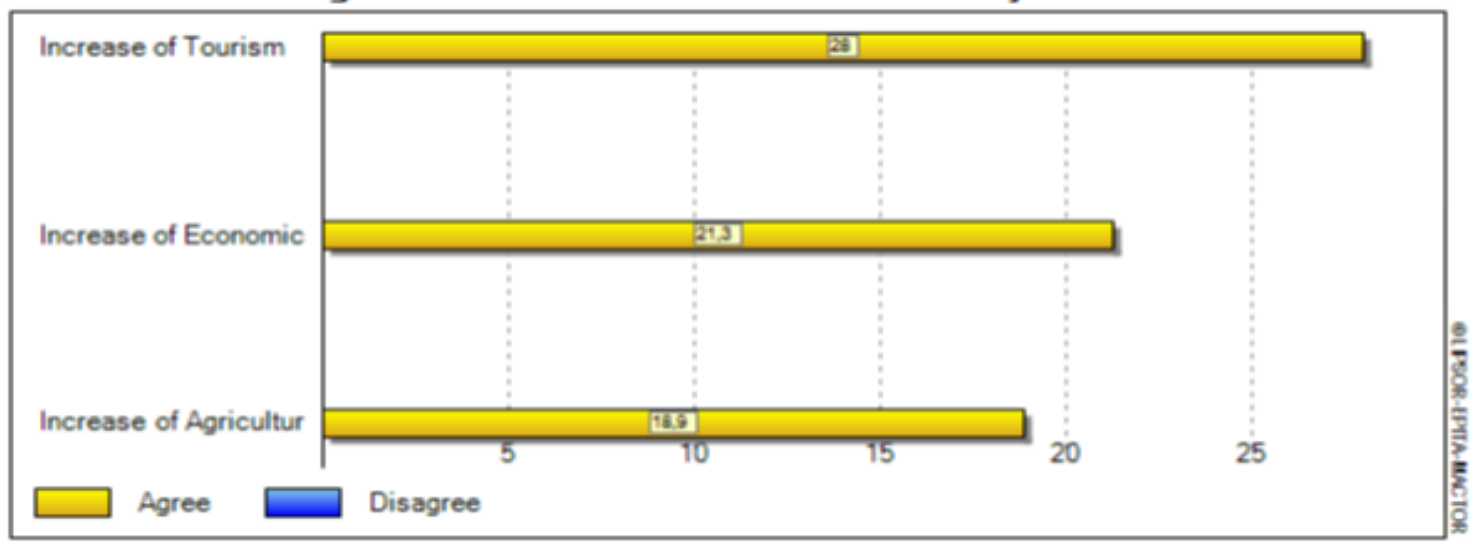

Figure 2 - Histogram of stakeholder implications for the purpose of agrotourism management 


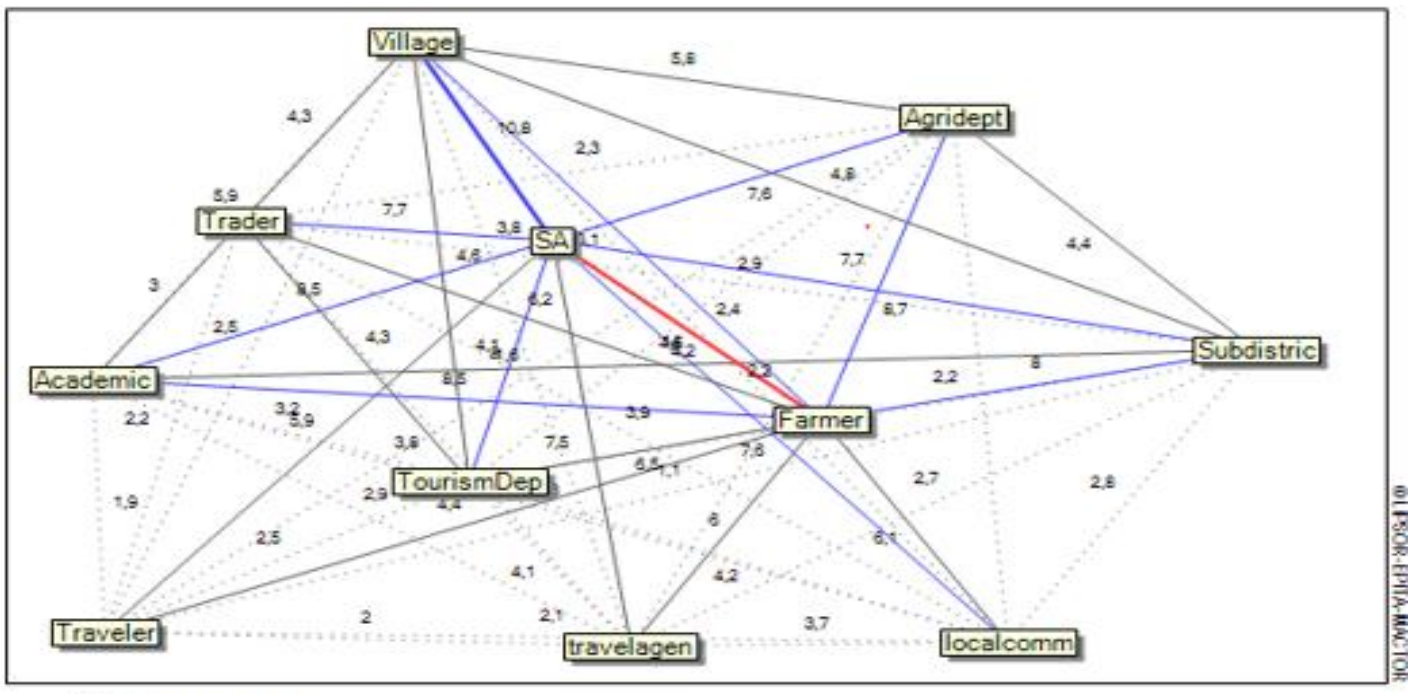

Weakest convergences

Weak convergences

Moderate convergences

Strong convergences

Figure 3 - Convergent graphs between stakeholders

Figure 3 shows that the Setiya Aji Flower Farm Manager converges very strongly with farmers. This is also proven by a matrix of interests and influences that place the two stakeholders in the key player position. This very strong relationship occurs because Setiya Aji managers are very dependent on the role of farmers who plant chrysanthemums as the main attraction of agro-tourism, and they also get the main income from managing agrotourism. Whereas farmers also have a high dependency on the existence of Setiya Aji Flower Farm agro-tourism because they not only get income from chrysanthemum harvest, they also get the profit sharing from agrotourism levy; in addition they can sell their crops to tourists at higher prices. The results of the convergence analysis illustrate that the management of Setiya Aji Flower Farm agro-tourism must prioritize the two existing economic activities, namely increased tourism and increased economy.

The governance of Setiya Aji Flower Farm in Figure 4 can be explained that the management of agro-tourism is still very simple with the concept of utilizing the pre-harvest period for tourism. A small scale management model by the local community with the biggest role for farmers and managers with the aim of increasing tourism potential and increasing agricultural yields which will later have an impact on increasing their income.

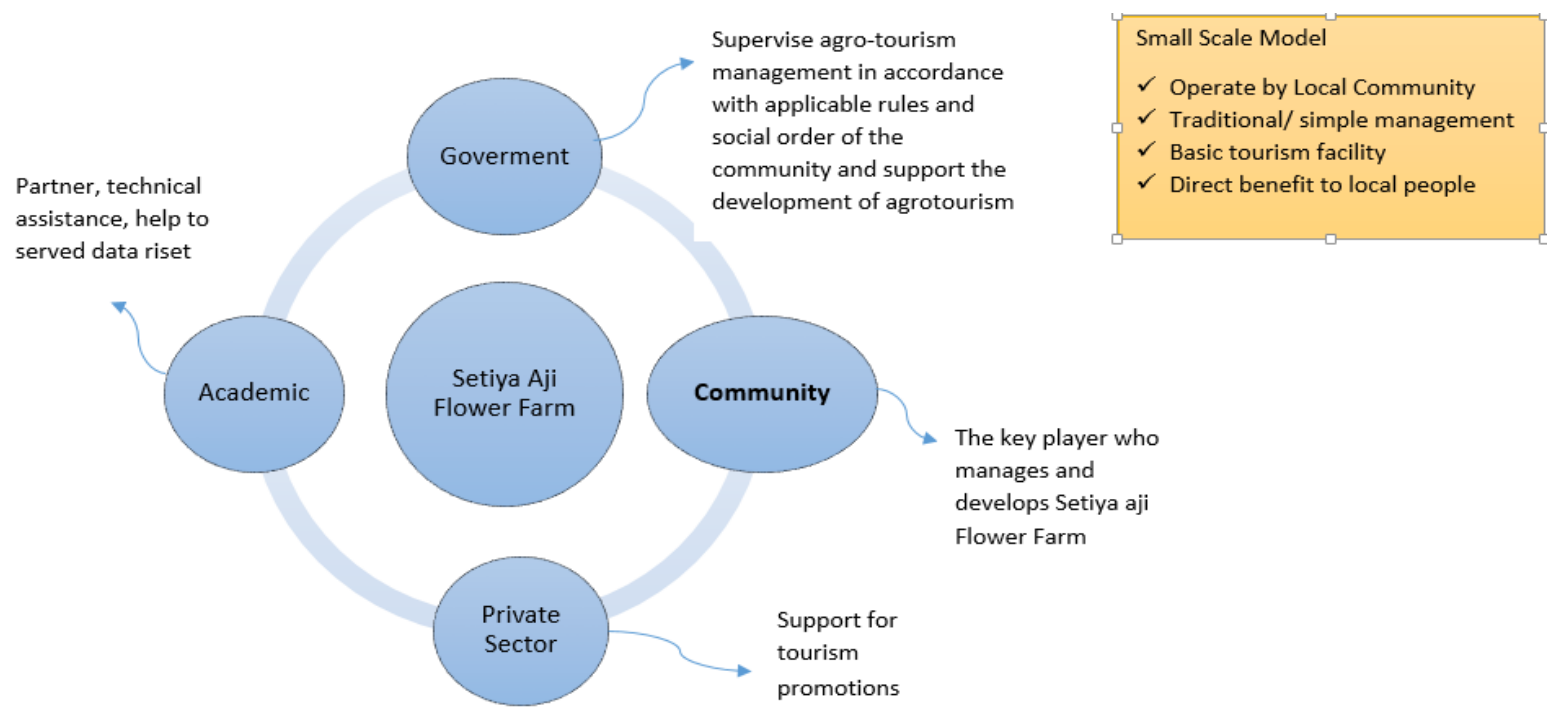

Figure 4 - Governance of Setiya Aji Flower Farm 
The management of Setiya Aji Flower Farm should be improved by cooperating with other stakeholders, namely the government, the private sector, academics so that sustainability occurs in the development of agro-tourism. With good management and focus will be able to prepare tourism actors to anticipate and be ready to adapt in every changes.

\section{CONCLUSION}

There are 11 stakeholders who play a role in the development of the Setiya Aji Flower farm tourism, namely the Government (Tourism Department, Agriculture Department, SubDistrict and Village), Community (Farmers, Setiya Aji Farm Management Group, Setiya Aji Farm Tourism Traders Group, local community and traveler), private sector (Travel agent) and academics. Included in the key player are Setiya Aji Flower Farm management, Farmers and Local Community. The three stakeholders have the biggest role and influence in the management of Setiya Aji Flower farm.

The governance of Setiya Aji Flower Farm is still fully managed by the local community, and the role of other stakeholders is only as a support. To make Setiya Aji Flower Farm develop and continue, it takes an active role and collaboration with the Government, academics and the private sector.

\section{REFERENCES}

1. Ariyanto. 2005. Ekonomi Pariwisata. Rineka Cipta. Jakarta.

2. Badan Pusat Statistik. 2017. Kabupaten Semarang Dalam Angka 2017. BPS Kabupaten Semarang.

3. Eden, C., \& Ackermann, F. (1998). Making strategy: the journey of strategic management. London: Sage Publications.

4. Farazmand, A. (2004). Sound governance: Policy and administrative innovations. Westport, CT: Praeger Publishers.

5. Handayani F and Warsono. H.2017. Analisis peran stakeholders dalam Pengembangan Objek wisata Pantai Karang jahe di kabupaten Rembang. Journal of Public Policy and Management Review. 6 (3): 40-53.

6. Hetifah, S.J, Sumarto. 2003. Inovasi Partisipasi, and Good Governance: 20 Prakarsa Inovatif and Partisipatif di Indonesia. Jakarta: Yayasan Obor Indonesia.

7. Idajati. H, Pamungkas. A, and Kukinl. V. S. 2015. The Level of Participation in Mangrove Ecotourism development, Wonorejo Surabaya. Procedia-Social and Behavioral Sciences. 227: $515-520$.

8. Lestari E.2017. Landasan program perencanaan and Perancangan Arsitektur Taman Wisata Bunga Krisan Bandungan. Skripsi S1.Universitas Diponegoro.Semarang.

9. Mafruhah.2019. Strategi Rekayasa Sosial, Perilaku Entrepreunership tenaga Kerja Indonesia pada Masa Penempatan. Disertasi S3. Universitas Diponegoro. Semarang.

10. Miftah A, Yanto.2017. Penyusunan renstra Desa Wisata Bunga Pada Kawasan Ekowisata Sebagai Upaya kesejahteraan Masyarakat Desa Jetis kecamatan Bandungan Kabupaten Semarang. Journal of Dedicators Community. 1 (2): 134.

11. Osman, Shaw and Kenawy. 2018. Examining the Extent to Which Stakeholder Collaboration During Ecotourism Planning Process Could Be Applied Within An Egyptian Context. Land Use Policy. 78 (126-137).

12. Pollinac R, R Pomeroy, and L. Bunce. 2003. Factors Influencing the Sustainability of Integrated Coastal Management Project in Central Java and North Sulawesi, Indonesia. Journal of Coastal and Marine Resources, Special Edition, No. 1.

13. Prayogi, Erwin. 2019. Model Pengelolaan Wisata Bahari Taman Nasional Ujung Kulon.Tesis S2.Universitas Diponegoro.Semarang.

14. Purwanti F, Alikodra, Basuni and Soedharma. 2010. Pengembangan Co-Management Taman Nasional Karimunjawa. Jurnal IImu Kelautan 13(3).pp. 159.

15. Rai Utama IG.2017. Pemasaran Pariwisata. Penerbit ANDI, Yogyakarta. 
16. Reed. M.S,Graves.,Dandy.A, Posthumus, H., Hubacek, K, J.Morris, C. Prell, C.H Quinn and L.C.Stringer.(2009). Who's in and why? A Typology of Stakeholder Analysis Methods for Natural Resource Management. Journal of Environmental Management, 90, 19331949.

17. Santoso,H. 2015.Model Pengembangan Tata Kelola Pariwisata di Taman Nasional Bunaken. Disertasi S3.Institut Pertanian Bogor. Bogor.

18. Satryanto, Adjie Pamungkas. 2015. Analisa Faktor-Faktor Yang Mempengaruhi Pengembangan Kawasan Wisata Bahari lhok Geulumpang, Aceh Jaya. Jurnal teknik ITS. Surabaya. C6-C10.

19. Setyaningrum A., Setyorini and Masduqi. 2017. Strategi Pengembangan Pariwisata Berbasis Sumber Daya Alam Pesisir and laut Di pantai depok daerah istimewa Yogyakarta. Jurnal Kebijakan Sosial Ekonomi Kelautan and Perikanan: 7 (2): 179

20. Suparmoko. 1997. Ekonomi Sumber Daya Alam and Lingkungan, Edisi Ketiga. Yogya: BPFE UGM.

21. Supohardjo. 2005. Strategi and Praktek Kolaborasi: Sebuah Tinjauan. Hal 3- 34. Suporahardjo (edt.). 2005. Manajemen Kolaborasi: Memahami Pluralisme Membangun Konsensus. Pustaka Latin. Bogor.

22. Susilowati, I.2012. Menuju pengelolaan Sumberdaya Perikanan Berkelanjutan yang Berbasis pada Ekosistem: Studi Empiris di Karimun Jawa, Jawa Tengah. Universitas Diponegoro, Semarang.

23. Widodo, Rinekso Soekmadi, Hadi Susilo Arifin.2018. Analisis stakeholders Dalam pengembangan Ekowisata Di Taman Nasional Betung Kerihun Kabupaten Kapuas Hulu. Jurnal Pengelolaan Sumber Daya Alam and Lingkungan. 8 (1): 55-61. 